\title{
Natural protective agents and their applications as bio-preservatives in the food industry:
}

\section{An overview of current and future applications}

\author{
Saber Amiri ${ }^{1}$, Zahra Motalebi Moghanjougi ${ }^{1}$, Mahmoud Rezazadeh Bari ${ }^{1 *}$, Amin Mousavi Khaneghah ${ }^{2 *}$ \\ ${ }^{1}$ Department of Food Science and Technology, Faculty of Agriculture and Natural Resources, Urmia University, Urmia, \\ Iran; ${ }^{2}$ Department of Food Science and Nutrition, Faculty of Food Engineering, State University of Campinas, Brazil
}

*Corresponding Authors: Mahmoud Rezazadeh Bari, Department of Food Science and Technology, Faculty of Agriculture and Natural Resources, Urmia University, Urmia, Iran. Email: m.rezazadehbari@urmia.ac.ir; Amin Mousavi Khaneghah, Department of Food Science and Nutrition, Faculty of Food Engineering, State University of Campinas, Brazil. Email: mousavi@unicamp.br

Received: 5 April 2021; Accepted: 30 April 2021; Published: 18 May 2021

(c) 2021 Codon Publications

OPEN ACCESS (c) (i) (ㄱ) ()

PAPER

\begin{abstract}
Today, the usage of natural additives in the food matrix has increased. Natural antimicrobial compounds include peptides, enzymes, bacteriocins, bacteriophages, plant extracts, essential oils, and fermented compounds that can be used as alternatives to chemical antimicrobials. Plant extracts and essential oils contain terpenes, flavonoids, aldehydes, and phenolic compounds that cause antimicrobial and antioxidant activity. The synergistic activity of compounds synthesized from lactic acid bacteria (LAB) prevents the growth of bacteria and fungi. In addition to removing mycotoxins, LAB compounds have antioxidant and anticancer potentials and increase food safety and nutritional value. One of these antimicrobial molecules is bacteriocin, which is made by various microorganisms. Nisin is one of these bioactive peptides that are used widely in food bio-preservation. Antimicrobial peptides can be used alone or along with other compounds to enhance food security. This article reviews natural preservatives and their applications in food products.
\end{abstract}

Keywords: bioactive compounds; antioxidants; protective culture; Antimicrobial peptides; bacteriocin; essential oils

\section{Introduction}

Microorganisms and lipid oxidation are important problems in food safety (Aziz and Karboune, 2018). Bacteria, yeasts, and molds are microorganisms that spoil food products (Figure 1) (Gonelimali et al., 2018). Many strains of Aspergillus and Penicillium produce mycotoxins that cause disease (Varsha and Nampoothiri, 2016). In general, the food industry relies on chemicals for food preservation. Food additives include the following: preservatives (antimicrobials, antioxidants, and anti-browning agents), nutritional additives, coloring agents (azo compounds, xanthan, chinophthalon derivatives, indigo, and triarylmethane), flavors (sweeteners and flavor enhancers), and textural ingredients (stabilizers and emulsifiers) (Carocho et al., 2018).

Usually, chemical preservatives are applied to prevent lipid oxidation and microorganisms growing in the food industry. The use of nitrite and sulfur dioxide (chemical preservatives) can have side effects on foods and human health. Owing to the extensive use of these substances, bacteria have become resistant, and consumers are looking for natural products with nonchemical preservatives, so there is a need to find natural preservatives (Amiri et al., 2021a; Mahmud and Khan, 2018; Pisoschi et al., 2018; Rai et al., 2016). With regard to these needs, biopreservation, super chilling, and active packaging were 


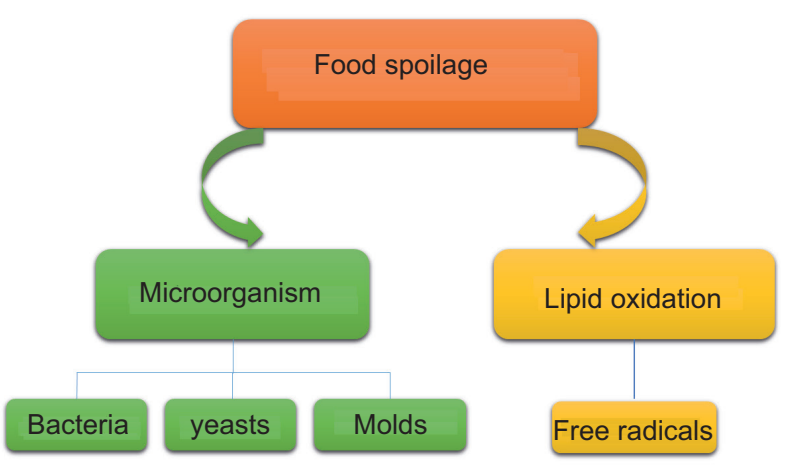

Figure 1. The cause of food spoilage.

considered (Aziz and Karboune, 2018; Tumbarski et al., 2020).

Most natural antimicrobial compounds include extracts (grape seed, tea, strawberry, cranberry, and blueberry), spices (garlic, nutmeg, cinnamon, clove, black pepper, and ginger) herbs (basil, oregano, rosemary, marjoram, and sage), enzymes (lysozyme, lactoferrin), bacteriocins (BACs) (nisin and natamycin), peptides, organic acids (propionic, citric acid, and sorbic), vitamins ( $\alpha$-tocopherol and ascorbic acid), and natural polymers (chitosan) (Table 1). They are added directly to foods or put into packaging because the latter is beneficial (Aziz and Karboune, 2018; Mahmud and Khan, 2018; Bai-Ngew et al., 2021; Sohrabpour et al., 2021). All herbal essential oils (EOs) and extracts have an inhibitory effect against viruses, bacteria, fungi, oxidative corruption, and insects (Xing et al., 2012). Various herbal and spice antimicrobial agents are used to eliminate foodborne microorganisms such as Listeria monocytogenes, Escherichia coli, Staphylococcus aureus, Bacillus cereus, and Salmonella, and to enhance the quality of different foods. The most common sources of EOs of clove, cinnamon, oregano, citrus, garlic, coriander, parsley, lemongrass, sage, rosemary, and vanillin are antimicrobial and antioxidant agents that are used in bioactive packaging of foods (Gonelimali et al., 2018; Mahmud and Khan, 2018).

Bio-preservation is applying bacteria or their bioactive metabolites to inhibit foodborne pathogens (Amiri et al., 2021b; Azizi et al., 2021; Gonelimali et al., 2018; Tumbarski et al., 2020). The most crucial advantage of antimicrobial peptides is that they do not alter food quality and are harmless (Rai et al., 2016). Lactic acid bacteria (LAB) is used as a protective culture in dairy foods due to the production of lactic acid, hydrogen peroxide, fatty acids, acetaldehyde, and BACs that inhibit the growth of microorganisms (Amiri et al., 2020a, 2020b, 2020c;

Table 1. Natural antimicrobials and antioxidants in the food industry.

\begin{tabular}{|c|c|c|c|c|}
\hline \multicolumn{5}{|c|}{ Natural preservatives } \\
\hline \multicolumn{3}{|c|}{ Natural Antimicrobial } & \multicolumn{2}{|c|}{ Natural antioxidant } \\
\hline \multirow[t]{5}{*}{ Plant based } & Essential oils & $\begin{array}{l}\text { Cinnamon, Oregano, Clove, Garlic, Rosemary, } \\
\text { Parsley, Coriander, Lemongrass, Rosemary, Allspice, } \\
\text { Litsea Cubeba, Sage, purple, and bronze Muscadine } \\
\text { seeds }\end{array}$ & Pigments & Anthocyanins, Anthocyanins \\
\hline & Spices & $\begin{array}{l}\text { black, white, cayenne Peppers, Mustard, Chillies, } \\
\text { Paprika, Coriander, Clove, Cumin, Dill fennel, Nutmeg, } \\
\text { Mace, Cinnamon, Garlic, Ginger }\end{array}$ & Spices & $\begin{array}{l}\text { Cinnamon, Cloves, Nutmeg, } \\
\text { Ginger, Black pepper, Garlic, } \\
\text { Onion, Cumin, Turmeric }\end{array}$ \\
\hline & Herbs & $\begin{array}{l}\text { Thyme, Basil, Bay leaf, Marjoram, Shallot, Onion, } \\
\text { Garlic, Oregano, Rosemary, Sage }\end{array}$ & Herbs & $\begin{array}{l}\text { Rosemary, Oregano, Marjoram, } \\
\text { Sage, Basil, Thyme }\end{array}$ \\
\hline & Extracts & Grape seed, Tea, Strawberry, Cranberry, Blueberry & Extracts & $\begin{array}{l}\text { Tea, Grape seed, Cranberry, } \\
\text { Blueberry, Strawberry, } \\
\text { Pomegranate, Citrus fruits }\end{array}$ \\
\hline & peptides & $\begin{array}{l}\text { Lipid transfer protein 2, Snakin1, Kalata B1, Thionin, } \\
\text { Defensins }\end{array}$ & Vitamins & $\alpha$-Tocopherol, Ascorbic acid \\
\hline \multirow[t]{3}{*}{ Animal based } & Enzymes & Lysozyme, Lactoperoxidase, & & \\
\hline & Peptides & $\begin{array}{l}\text { Pleurocidin, Protamine, Magainins, Sarco toxin, } \\
\text { Hymenoptaecin, Attacin, Diptericin, Coleoptericin, } \\
\text { Lactoferricin, kappacin, k-casecidin, S1- S2- A-B } \\
\text { Caseins }\end{array}$ & & \\
\hline & Natural polymers & Chitosan, Poly-L-Lysine & & \\
\hline \multirow{4}{*}{$\begin{array}{l}\text { Microbial } \\
\text { based }\end{array}$} & Enzymes & Glucose oxidase & & \\
\hline & Bacteriophages & ListexTMP100, EcoshieldTM, SalmofreshTM & & \\
\hline & Organic acids & Propionic, Citric acid, Sorbic, Lactic acid & & \\
\hline & Bacteriocins & Nisin, Natamycin, Enterocin, Pediocin, Reuterin, & & \\
\hline
\end{tabular}


Rai et al., 2016; Tumbarski et al., 2020). BACs are ribosomally synthesized proteins or peptides from certain bacteria. BACs are efficient against antibiotic-resistant pathogens such as $S$. aureus and Enterococcus faecalis without showing toxicity (Ahmad et al., 2017; Amiri et al., 2021c; Mahmud and Khan, 2018). LAB produces a diversity of antifungal compounds and may be used as a bio-protective without changing the organoleptic characteristics. LAB has been found naturally in various foods for centuries and has been used in fermented foods without side effects. It is known as GRAS (generally recognized as safe) (Amiri et al., 2019a; Favaro et al., 2015; Maleki et al., 2020; Rezazadeh-Bari et al., 2019; Varsha and Nampoothiri, 2016). The Food and Drug Administration of USA (FDA) accepted LAB as a safe agent for fermented foods (Upendra et al., 2016). It is heat resistant and has a tremendous antimicrobial effect against Gram-positive $\left(\mathrm{G}^{+}\right)$and Gram-negative $\left(\mathrm{G}^{-}\right)$ pathogens after pasteurization and also does not alter the taste, aroma, or texture and physical, chemical, or biological properties of foods (Figure 2) (Rai et al., 2016).

\section{Natural Antimicrobial Agents}

\section{Plant-based antimicrobial agents}

\section{Essential oils}

Essential oils (EOs) are natural and volatile compounds determined by odor and taste (Mohajeri et al., 2021; Ghamari et al., 2021; Regnault-Roger et al., 2012). EOs are include terpenes, alcohols, acids, esters, epoxides, aldehydes, ketones, amines, and sulfides. They are synthesized in the cytoplasm and plastids of plant cells through malonic acid, mevalonic acid, and Methyl-D-erythritol4-phosphate pathway. Terpenes are hydrocarbons and consist of various isoprene units. At the same time, terpenoids are made from the biochemical alteration of terpenes by enzymes that add oxygen molecules and transfer methyl. Terpenoids have high antimicrobial activity (Pisoschi et al., 2018). The constituents in EOs are the following groups: terpenes and terpenoids that are more effective to $\mathrm{G}^{+}$bacteria (Mahmud and Khan, 2018). $\mathrm{G}^{-}$bacteria's resistance is due to the presence of an outer membrane of lipopolysaccharide around the cell wall (Tongnuanchan and Benjakul, 2014). However, there are reports that EOs of cinnamon, oregano, clove, garlic, rosemary, parsley, coriander, lemongrass, sage, purple, and bronze muscadine seeds are effective on both types of bacteria, many of which are carvacrol, thymol, eugenol, and citral (Aziz and Karboune, 2018; Irkin and Esmer, 2015). EOs of cinnamon, oregano, clove, garlic, coriander, parsley, lemongrass, rosemary, and sage have good effects. EOs with great amounts of eugenol (allspice, clove, and cinnamon), trans-cinnamaldehyde (cinnamon), and citral (litsea cubeba, lemon myrtle, and lime) have strong effects (Dussault et al., 2014).

The oregano EO has irreversible damage (in $1 \mathrm{~min}$ ) against E. coli O157: $\mathrm{H} 7$ cells (Pisoschi et al., 2018). The role of oregano, thyme, and savory as an antimicrobial agent is because of phenolic compounds caracole, thymol $\rho$-cumene, and y-terpinene (Aziz and Karboune, 2018; Dussault et al., 2014). The existence of a hydroxyl group in the structure of phenolic compounds and its position is the reason for the antimicrobial effect. The antimicrobial effect of sage is caused by terpene thujone. Rosemary EO has an inhibitory effect against $\mathrm{G}^{-}$bacteria (E. coli, Klebsiella pneumonia) and $\mathrm{G}^{+}$bacteria (Bacillus subtilis, S. aureus) (Aziz and Karboune, 2018; Tongnuanchan and Benjakul, 2014). This is because of terpene groups such as borneol, camphor, 1, 8-cineole, a-pinene, camphone,

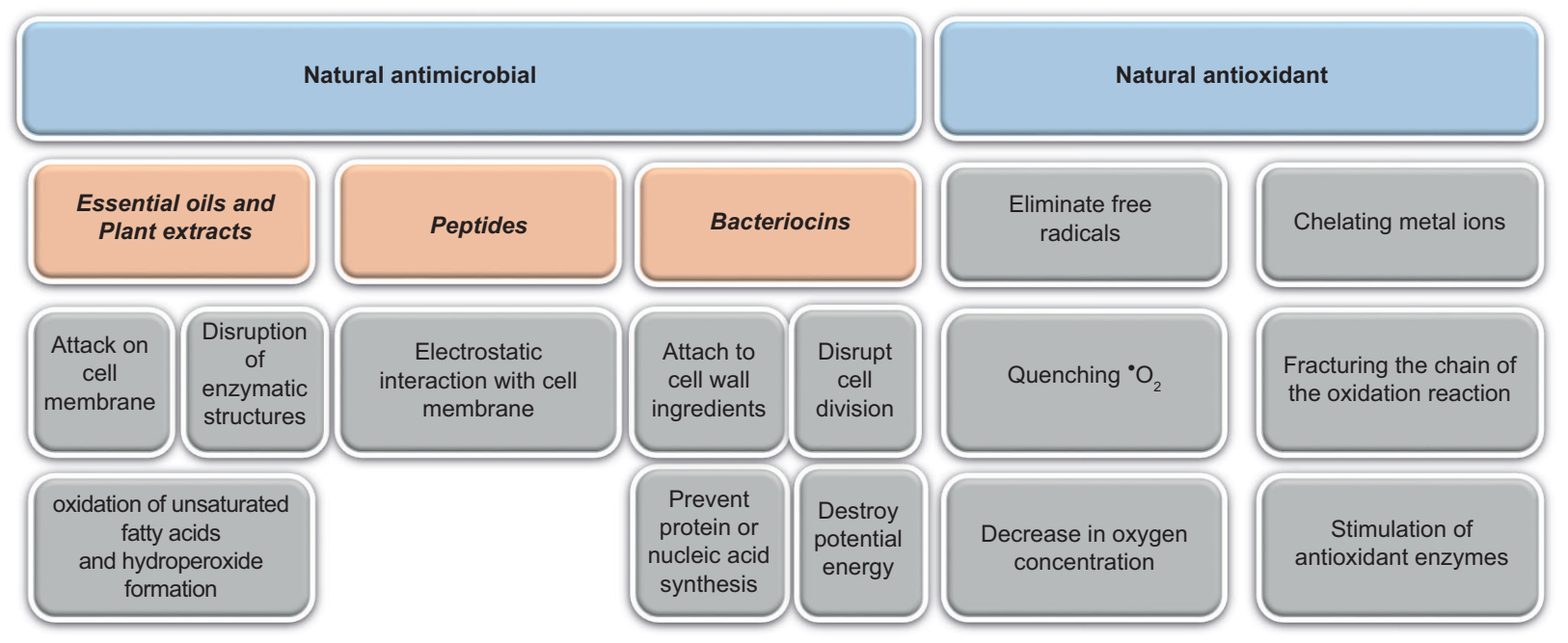

Figure 2. Mechanisms of action of natural protective agents. 
verbenonone, and bornyl acetate. The antimicrobial activity of garlic and onion is due to allicin and mustard caused by allyl and isothiocyanates. Allyl isothiocyanate is effective against fungi and $\mathrm{G}^{-}$bacteria (Aziz and Karboune, 2018). Ginger, oregano, rosemary, sage, thyme, and peppermint are significant sources of EOs and include alcohols, aldehydes, phenylpropanoids, terpenes, and ketones that are antioxidants. In addition to antioxidant activities, EOs can provide antibacterial activity $(S$. aureus, E. faecalis, E. coli, Clostridium perfringens, and Clostridium sporogenes) in meat foodstuffs (Mahmud and Khan, 2018). Marei et al. (2012) studied 12 monoterpenes' antifungal activity against Rhizoctonia solani, Fusarium oxysporum, and Penicillium, and digitatum and Aspergillus niger thymol were the good antifungal compounds comparable to fungicide and carbendazim. Allyl isothiocyanate, cinnamon oleoresin, cinnamon Chinese cassia, and oregano Chinese cinnamon EOs have antimicrobial activity against $E$. coli $\mathrm{O} 157: \mathrm{H7}$, S. aureus, B. cereus, L. monocytogenes, and Salmonella enterica serovar typhimurium. The coriander seed oil has antimicrobial efficacy against $\mathrm{G}^{+}$and $\mathrm{G}^{-}$bacteria, some yeasts, dermatophytes, and molds (Silva and Domingues, 2017). Low $\mathrm{pH}$, temperature, and oxygen content can complete EOs' performance (Aziz and Karboune, 2018; Dussault et al., 2014). These compounds are GRAS and can be used as food additives (Mahmud and Khan, 2018; Bai-Ngew et al., 2021).

\section{Mechanisms of action}

Plant material affects microorganisms through various mechanisms, such as attacking the cell membrane, disrupting enzymatic structures, compromising bacterial genetic material, and fatty acid hydroperoxide formation by oxygenation of unsaturated fatty acids (Tajkarimi et al., 2010). The function of phenolic compounds of EOs likely depends on alteration of bacterial cell permeability, damage to the cytoplasmic membrane, disruption of the cellular production system of cellular energy (ATP), proton motility, and cell death that occurs by damaging the cytoplasmic membrane (Mahmud and Khan, 2018).

\section{Herbs and spices}

Herbs are obtained from the same plant's leaves, but spices are obtained from different parts of the plant. Herbs and spices are divided into the following categories: hot spices (peppers), mild flavor spices (paprika and coriander), aromatic spices (clove, cumin, dill fennel, nutmeg, mace, and cinnamon), and aromatic herbs and vegetables (thyme, basil, marjoram, shallot, onion, and garlic). Phytochemicals are bioactive compounds that contain flavonoids and other phenolic ingredients, carotenoids, plant sterols, glucosinolates, and other sulfur compounds. Extracts and herbs act against $\mathrm{G}^{+}$bacteria. Also, the shelf life can increase using bioactive ingredients such as phenol, alcohol, aldehyde, ketone, esters, and hydrocarbons (cinnamon, cloves, garlic, mustard, and onions) (Embuscado, 2015; Mahmud and Khan, 2018). Cinnamon has antibacterial activity against both types of bacteria, such as B. cereus, L. monocytogenes, S. aureus, E. coli, and Salmonella anatum (Shan et al., 2007).

\section{Plant extracts \\ Grape seed and green tea extracts}

Grape seeds contain high amounts of phenolic compounds, including catechin, epicatechin, epicatechin-3$\mathrm{O}$-gallate, dimeric, and trimeric tetrameric procyanidins. Green tea leaves have epicatechin, epicatechin gallate, epigallocatechin, teaflavin gallate, teaflavin monogallate $\mathrm{A}$, and $\mathrm{B}$ teaflavin digallate. Extracts of grape and green tea postpone growing of microorganisms in raw beef (Banon et al., 2007). Tea phenols have antimicrobial properties against both types of bacteria. The antimicrobial effect of arrowroot tea is related to catechins. Green tea has antibacterial activity against pathogens (Kim and Fung, 2004). It has been reported that grape seed extract decreased E. coli O157: H7 and S. Typhimurium, and postponed the growth of L. monocytogenes and Aeromonas hydrophila in cooked meat (Aziz and Karboune, 2018). Antibacterial compounds of coffee are caffeic acid, chlorogenic acid, and protocatechuic acid. The growth of E. coli O157: $\mathrm{H} 7$ is inhibited by trimethylated alkaloid caffeine (Ibrahim et al., 2006).

\section{Cranberry extracts}

Phenolic compounds, such as low molecular weight phenolic acids, condensed tannins, proanthocyanidins, and flavonoids (anthocyanins, especially proanthocyanidins), which are composed of tetramers of type A and pentamer type A, are the main factors of antimicrobial activity in cranberry (Khaneghah et al., 2018). Extract of cranberry fruit at $15 \%$ concentration inhibited $A$. hydrophila, B. cereus, Enterobacter aerogenes, E. coli, K. pneumonia, Proteus vulgaris, P. aeruginosa, S. typhimurium, S. aureus, and Yersinia enterocolitica (Sagdic et al., 2006).

\section{Mechanisms of action}

An accurate way has not yet been elucidated. Nevertheless, plant substances can be affected by attacks on the cell membrane's phospholipid bilayers, disruption of enzyme activity, endangering the genetic material of bacteria, and oxidation of unsaturated fatty acids (Tajkarimi et al., 2010). The inhibitory activity of aromatic and phenolic compounds is due to affecting the cytoplasmic membrane's structure and function. The outer membranes of E. coli and S. typhimurium was dissipated after exposure to carvacrol and thymol. The antimicrobial effect of nonphenolic isothiocyanates is due to the denaturized of extracellular enzymes. Terpenes can disrupt and affect the bacterial cell wall's fat composition 
and ultimately cause bacterium death (Aziz and Karboune, 2018). Carvacrol can split $\mathrm{G}^{-}$bacteria's outer membrane diffusing lipopolysaccharides and enhancing the permeability to ATP. Its activity against $\mathrm{G}^{+}$bacteria is because of its interplay through the bacterial membrane, which changes $\mathrm{H}^{+}$and $\mathrm{K}^{+}$cations (Tongnuanchan and Benjakul, 2014).

\section{Animal-based antimicrobial agents}

\section{Enzymes}

\section{Lysozyme}

It is an enzyme and natural antimicrobial agent that hydrolyzes the-beta 1, 4 glycosidic bonds between $\mathrm{N}$-acetylmuramic acid and $\mathrm{N}$-acetyl glucosamine existing in peptidoglycan. $\mathrm{G}^{+}$bacteria are sensitive to lysozyme since $90 \%$ of these bacteria's cell wall is composed of peptidoglycans. Therefore, it is a natural antimicrobial agent (Irkin and Esmer, 2015). G- bacteria are resistant to lysozyme because of the lipopolysaccharide layer, which prevents lysozyme from approaching the peptidoglycan layer. However, this enzyme can also affect $\mathrm{G}^{-}$ bacteria if membrane destabilizing factors, for example, detergents and chelating agents, are present. Lysozyme has a high resistance to a wide range of temperatures and $\mathrm{pH}$, which enables its usage in edible active films (Bayarri et al., 2014). Inovapure is a commercial lysozyme studied in model studies, either alone or with other compounds, against L. monocytogenes, Clostridium botulinum, Campylobacter jejuni, Pseudomonas spp., Salmonella enteritidis, Clostridium thermosaccharolyticum, Bacillus stearothermophilus, and Clostridium tyrobutyricum. Lysozyme derived from egg white has been allowed by Health Canada to be used in hard cheeses to inhibit the gas blowing of C. tyrobutyricum (Aziz and Karboune, 2018; Baines and Seal, 2012). Lysozyme has also been assayed in eggs, milk, beef, and part in edible films and coatings, along with other antimicrobial materials (Bayarri et al., 2014).

\section{Lacto-peroxidase system}

One of the natural antimicrobial systems is the lactoperoxidase system obtained from milk, saliva, and tears. It consists of lactoperoxidase, thiocyanate, and hydrogen peroxide. Lacto-peroxidase accelerates the oxidation of thiocyanate ions using $\mathrm{H}_{2} \mathrm{O}_{2}$. Afterward, hypothyroidism and acid hypothyroidism show inhibitory effects on microorganisms through the oxidation of sulfhydryl groups to enzymatic systems and proteins. It shows antimicrobial activity against bacterial and fungal species (Campos et al., 2011). The general application of lactoperoxidase is to preserve raw milk (especially if the refrigerator is not available). Because thiocyanate in milk is not enough to stimulate the lactoperoxidase system's activity, thiocyanate should be added. Its use in juice storage and food coating is suggested (Marcio Carocho et al., 2018). Considerations of using the lactoperoxidase system in packaging films depend on the cost and the antimicrobial activity of the lactoperoxidase system (thiocyanate and $\mathrm{H}_{2} \mathrm{O}_{2}$ ). If $\mathrm{H}_{2} \mathrm{O}_{2}$ levels are exceeded in food products, it may raise toxicological concerns (Aziz and Karboune, 2018).

\section{Antimicrobial peptides \\ Eukaryotic peptides}

Animal peptides. Mammalian antimicrobial peptides are secreted into mucosal, epithelial, and paneth cells. Mammalian leukocytes are a rich origin of cationic antimicrobial peptides that prevent bacterial infection. Several of them can rapidly destroy the lipid layer of the cell membranes of microorganisms. In addition to inhibition of both types of bacteria, they also have antifungal and antiviral activity. These are considered a suitable option for antibiotic resistance (Aires et al., 2009; Tiwari et al., 2009). Pleurocidin and protamine isolated from fish have antimicrobial activity on $\mathrm{G}^{-}$bacteria such as Vibrio parahemolyticus, L. monocytogenes, E. coli O157:H7, Saccharomyces cerevisiae, and Penicillium expansum. Nevertheless, magnesium and calcium prevent their efficacy (Burrowes et al., 2004). Magainins from amphibians have shown extensive activity against both types of bacteria and are generally used to preserve meat and cheese (Rai et al., 2016).

Insect's peptides. Antimicrobial peptides such as sarco toxin IIA, hymenoptaecin, attacin, diptericin, and coleoptericin act against Micrococcus luteus, Aerococcus viridians, Bacillus megaterium, B. subtilis, Bacillus thuringiensis, and S. aureus secreted by insects (Wang et al., 2016).

Plant peptides. These peptides are cysteine-rich (molecular weight 2-9 kDa), such as lipid transfer protein 2, Snakin1, Kalata B1, thionin, and potato defensins. They have antimicrobial effects against L. monocytogens, S. Typhimurium, and E. coli O157:H7. In particular, defensins have antimicrobial potential against microorganisms (Rai et al., 2016; Tiwari et al., 2009).

Milk peptides. Lactoferricin (an $80 \mathrm{kDa}$ iron-binding glycoprotein), kappacin, and k-casecidin are antimicrobial peptides of milk proteins. Lactoferrin (as a GRAS) is an iron-binding glycoprotein with antimicrobial effect on both types of bacteria, such as Salmonella and E. coli, and fungi. In the past, it was used in baby formulas and to treat beef carcasses, but currently, lactoferrin approved in the USA for use on beef (Aziz and Karboune, 2018; Baines and Seal, 2012; Rai et al., 2016; Tiwari et al., 2009). Casocidin is a byproduct of the casein hydrolysis and has an antibacterial effect against Staphylococcus spp., 
Sarcina spp., B. subtilis, Diplococcus pneumoniae, and Streptococcus pyogenes. Casein A and casein B inhibit the growth of Enterobacter sakazakii. The peptides containing an S2-casein, an S1-casein, and k-casein have good inhibitory effect on E. coli and B. subtilis (Elbarbary et al., 2012).

\section{Mechanisms of action}

Antimicrobial peptides act through an electrostatic interaction with the membrane and have a permeability function. They can enter the membrane and eventually disrupt it (Rai et al., 2016). Several mechanisms are responsible for antibacterial activity of lactoferrin: prevention of growing by isolating iron from pathogens, the potential of cations in the surface of lactoferrin for a direct reaction with lipid $\mathrm{A}$, and modifying the permeability of the outer membrane and causing the release of lipopolysaccharide (Jenssen and Hancock, 2009).

\section{Chitosan}

Chitosan is natural cationic linear polysaccharides made up of $(1,4)$ linked 2 -amino-deoxy- $\beta$-D-glucan. Sources of chitosan are shrimp shells, fungi, and green algae (Dutta et al., 2009; Irkin and Esmer, 2015). It is effective against most microorganisms (both types of bacteria, yeasts, and molds). Due to the positive charge on $\mathrm{C}_{2}$ of glucosamine monomer at $\mathrm{pH}$ below 6 , chitosan is soluble than chitin and has higher antimicrobial effect (Irkin and Esmer, 2015). The positively charged amino group of chitosan can interact with the negatively charged cell membrane, causing leakage of intracellular compounds of microbes. Chitosan can inhibit toxin synthesize and bacterial growth by chelating the trace metals. It can activate some protection systems in the host tissue and prevent several enzymes' activity. Also, it can penetrate the nucleus of microorganisms and interfere in the translation process. The inhibitory mechanism of chitosan is diverse in $\mathrm{G}^{+}$ and $\mathrm{G}^{-}$bacteria; antimicrobial effect on $E$. coli increases with decreasing molecular weight of chitosan, while it has the opposite effect on S. aureus (Aziz and Karboune, 2018; Pisoschi et al., 2018).

\section{Microbial-based antimicrobial agents}

\section{Glucose oxidase}

Glucose oxidase is synthesized by $A$. niger and Penicillium spp. Glucose oxidase is an oxidoreductase that catalyzes the oxidation of D-glucose to $\mathrm{H}_{2} \mathrm{O}_{2}$ and D-glucono- $\delta$ lactone. D-glucono- $\delta$ - lactone reacts with water to form $\mathrm{D}$-gluconic acid. The antimicrobial role of glucose oxidase is because of the cytotoxicity of $\mathrm{H}_{2} \mathrm{O}_{2}$, lowering of $\mathrm{pH}$ by the formation of $\mathrm{D}$-gluconic acid. Hydrogen peroxide levels may also exceed the acceptable levels by the FDA and cause toxic problems. Long-dated disposal of foods to $\mathrm{H}_{2} \mathrm{O}_{2}$ can enhance lipid oxidation and lead to laxity. $\mathrm{H}_{2} \mathrm{O}_{2}$ can be removed from foods using catalase, which changes it to water and oxygen. Microbial glucose oxidase is allowed to remove oxygen and preserve taste and aroma in bottled beverages and is used as an additive in bakery products, flour, yolk, and white egg. D-gluconic acid, a catalytic product of glucose oxidase, is secure, and the WHO does not have a regulation for it (Aziz and Karboune, 2018).

\section{Bacteriophages}

Bacteriophages are viruses that attack bacteria. Lithium bacteriophages disrupt the metabolism of bacteria that results in bacterial death. Bacteriophages have been shown to be innocuous to mammalian cells, so they can be used for biological control of pathogens in foods (Carvalho et al., 2017). Bacteriophages are suitable for use in carcasses, vegetables, and fruits to increase various food products' shelf life. In 2006, ListexTMP100 and LMP102 bacteriophages were accepted by the FDA to control L. monocytogenes contamination, and in 2010, approved the use of ListexTMP100 against L. monocytogenes in meat, fish and poultry, vegetable, and some dairy products (Chibeu et al., 2013). In 2014, Canadian Health accepted the use of EcoshieldTM in meat to control E. coli O157: H7 and SalmofreshTM to control Salmonella growth in all foods (Aziz and Karboune, 2018). Bacteriophages have been investigated as antimicrobial agents in food packaging by immobilization on cellulose membrane or by encapsulating phages in alginate beads (Lone et al., 2016). Also, chitosan film contains liposome-encapsulated beef meat storage (Cui et al., 2017).

\section{Fermented ingredients}

Fermentation ingredients can be prepared by propionic acid bacteria and LAB from raw materials such as milk, sugar, or plant materials. The preservative role of LAB is because of producing organic acids (acetic, lactic, propionic, and formic acids) diacetyl, acetylene, hydrogen peroxide, fatty acids, antifungal agents (phenyl-lactate, hydroxyphenyl-lactate, propionate, cyclic dipeptides, and 3-hydroxy fatty acids), and the BACs (reuterin, reutericyclin, nisin, pediocin, lacticin, and enterocin). LABs are used as antimicrobials and sugars, sweeteners, polymers, disinfectants, aromatic compounds, and various enzymes (Favaro et al., 2015).

\section{$L A B$ and bio-preservation}

The biologically active ingredients in kimchi, such as benzyl isothiocyanate, indole, thiocyanate, and cystosterol, are antibiotics, anticancer, and immune stimulation. LAB was used to prevent L. monocytogenes and S. enteritidis in poultry and inhibition of S. typhimurium, E. coli, and L. monocytogenes in lettuce and apples. Enterococcus and Pediococcus were used to vacuum-package cold-smoked salmon (Varsha and Nampoothiri, 2016). MicrogardTM 
is a commercial milk supply that is fermented by dairy microorganisms. MicrogardTM could be effective against G- bacteria (Yersinia, Salmonella, and Pseudomonas) and some fungi but ineffective against the $\mathrm{G}^{+}$bacteria (L. monocytogenes, S. aureus, and B. cereus). FDA has approved propionibacterium metabolites as GRAS. The MicrogardTM products are used in dairy desserts, cheese, yogurt, pasta, sauces, and others (Aziz and Karboune, 2018; Favaro et al., 2015). LAB produces antifungal compounds, for example, hydroxyl fatty acids, organic acids, low molecular weight bioactive ingredients, and proteinaceous components. Some species of Enterococci, Lactobacilli, Pediococci, and Lactococci are also known as antifungal agents (Favaro et al., 2015; Gholam-Zhiyan et al., 2021). The antifungal effect of Lactococcus lactis on Aspergillus, Penicillium, Mucor, and Rhizopus has been reported (Oranusi et al., 2013). Also, Lactobacillus acidophilus and Bifidobacterium bifidum were efficient in preventing $A$. niger from growing on the surface of brined white cheese (Moghanjougi et al., 2020). Use of L. plantarum on Botrytis cinerea, Glomerella cingulate, Phytophthora drechsleri, P. citrinum, and F. oxysporum and application of Lactobacillus and Weisella cultures on A. niger, Candida albicans, Aspergillus tubingensis, and P. crustosum have been reported (Varsha and Nampoothiri, 2016). Feedtech Silage F3000 is a commercial compound of antifungal bacteria (L. plantarum Milab 393, P. acidilactici, E. faecium, and L. lactis) that improves growth beneficial bacteria and prevents yeast fungi and Clostridia. DuraFresh (Kerry) is also a commercial preservative derived from the fermentation of LABs that inhibits $\mathrm{G}^{-}$bacteria, yeast, and mold. ALTA 2341 is another fermented product. Therefore, the use of LAB in food has existed for a long time, and recent studies indicate their potential as an alternative to chemical preservatives (Varsha and Nampoothiri, 2016).

\section{Bacteriocins}

BACs are ribosomal antimicrobial proteins that usually have antimicrobial activity against similar genetic strains. The beneficial properties of BACs are stability to high temperature and low $\mathrm{pH}$ and sensibility to proteolytic enzymes. Their application can decrease the intensity of heat treatment and the use of chemical preservatives. Also, BACs and other methods as a hurdle can be helpful (Favaro et al., 2015). BACs are used in food products because they are harmless, do not change foods' nutritional characteristics, are efficient in low concentration, and active in refrigerator storage, and, therefore, an ideal bio-preservation (Mahmud and Khan, 2018; Milicevic et al., 2021). BACs isolated from $\mathrm{G}^{+}$bacteria are classified into the following groups: Class I, Class II, Class III, and Class IV. Class I are divided into (A, B, and C) subgroups: Type A corresponds to linear peptides and is further subdivided into two subgroups including AI subtype contains nisin like (nisin A, nisin U, streptin), and subtype AII contains SA-FF22 like (SA-FF22, lacticin 481, salvaricin A, sublancin 168). Type B are spherical peptides such as meracidin and cinnamycin belong to globular peptides, and type $\mathrm{C}$ are a few details BACs such as lactin, 3147 and cytolysin, that made by more than one part and biological activities are needed. Class II BACs are divided into (IIa, IIb, and IIc) subgroups: type IIa is related to pediocin (pediocin $\mathrm{Pa}-1$, carnobacteriocin $\mathrm{B} 2$, listerocin 743A, and ubericin A), type IIb is related to multifactorial BACs (lactococcin G, thermophilin 13, lactacin F, and lactocin 705), and Type IIc are sundry such as sakacins $\mathrm{Q}, \mathrm{T}$, and $\mathrm{X}$, and aureocin A53. Class III contains lysins (class IIIa) and nonlytic BACs (class IIIb). Class IV contains circulating inhibitory peptides such as enterocin AS-48 (Favaro et al., 2015; Milicevic et al., 2021).

\section{Nisin}

Nisin is produced by fermenting milk modified by the strains of L. lactis. Nisin is a Canadian Food and Drug and Health License and is accepted as a preservative in more than 48 countries. Nisin is efficient on most $\mathrm{G}^{+}$ bacteria such as L. monocytogenes and S. aureus, and Ethylenediaminetetraacetic acid (EDTA) can also inhibit $\mathrm{G}^{-}$bacteria (Aziz and Karboune, 2018; Campos et al., 2011; Pisoschi et al., 2018).

\section{Enterocin}

Enterocin AS-48 is one of the cyclic BACs that exhibit significant stability in $\mathrm{pH}$ and heat. The effectiveness of AS-48 for the control of staphylococci in culture has been represented. Also, chemical preservatives (sodium nitrite, sodium lactate, and sodium chloride), clusters, and temperate heat are in synergy with AS-48 on B. cereus, S. aureus, Salmonella choleraesuis, and E. coli O157:H7 (Favaro et al., 2015). Enterocin AS-48 has the ability to eliminate the parasitic protozoan Trypanosoma brucei, and Enterocin V effectively decreases C. albicans (Martínez-García et al., 2018).

\section{Pediocin}

Pediocins are produced by $P$. acidilactici and $P$. pentosaceus. They are thermal resistant and can work in a wide range of $\mathrm{pH}$. Pediocins have an antimicrobial effect against L. monocytogenes, E. faecalis, S. aureus, C. perfringens, and Oenococcus oeni. Pediocin can be used in dairy products or as a film in crushed ham and vegetables (Díez et al., 2012; Juneja et al., 2012).

\section{Natamycin}

Natamycin is a polyene macrolide that is synthesized by streptomyces species with an antifungal activity that has almost no effect on bacteria, protozoa, and viruses. Natamycin is associated with ergosterol, so it does not develop resistance in fungi. It has been used as a free, encapsulated, or film-forming agent to control yeast growth in cheese, salami sausages, and beverages (Pisoschi et al., 2018). 


\section{Reuterin}

Reuterin (b-hydroxypropionaldehyde) is a BAC produced by $L$. reuteri that affects both types of bacteria (L. monocytogenes, S. aureus, S. typhimurium, and E. coli). It is soluble in water and stable to temperature and proteolytic and lipolytic enzymes. It is characterized by resistance in a wide range of $\mathrm{pH}$. Reuterin is used in combination with lactobacillus in glycerol as starter cultures in cheese or as pure extract at the level of sausages and salmon or inside cheese (Gyawali and Ibrahim, 2014; Montiel et al., 2014).

\section{Mechanisms of action}

BACs affect the basic functions of living cells such as transcription, translation, replication, and cell wall biosynthesis, but most of the time, destroy the potential energy of sensitive cells by creating channels or pores in the membrane (Milicevic et al., 2021). BACs perform their function on bacteria (both types of bacteria) by disrupting cell division and preventing protein or nucleic acid synthesis, using various mechanisms. BACs can attach to cell wall ingredients using specific or nonspecific receptors, such as the lipid-binding site or the molecular surface, leading to the formation of pores or direct cell lysis and ultimately to death through the loss of the proton motor bacterial system. Nisin is a more effective combination with EDTA attacking the cytoplasmic membrane of $\mathrm{G}^{-}$bacteria due to the chelating effect of EDTA on cell wall components. By inhibiting the cell wall, mercasidine eliminates $\mathrm{G}^{+}$bacteria. Colicin eliminates $\mathrm{G}^{-}$bacteria's membrane pore-forming mechanism (Ahmad et al., 2017; Mahmud and Khan, 2018).

\section{Poly-L-Lysine}

Poly-L-Lysine is a lysine homopolymer as a GRAS that is used as a staple in foods. Large quantities produce a bitter flavor. It has high antimicrobial power, so it is used in small quantities. It also acts better with other antimicrobial agents. It is used in rice, noodles, soups, salads, cakes, custard, and for external protection of fish and sushi (Baines and Seal, 2012).

\section{Natural Antioxidant Agents}

Oxidation of lipids is the most important cause for the lower quality of foods (Prakash et al., 2012). Antioxidants inhibit oxidation by preventing the making of free radicals or by stopping their release-large amounts of synthetic antioxidants (BHA or BHT) may be carcinogenic in some animals. Therefore, natural antioxidants are a good option (Ahmad et al., 2015). Foods that use antioxidants include meat, dairy, oil, fried or extruded foods, and sauces (Baines and Seal, 2012). All polyphenol derivatives (phenolic-hydroxybenzoic acids or hydroxyquinamic acids, flavonoids including anthocyanins, tannins, lignins, acetylbases, and coumarins) due to high antioxidant ability and health properties can be used as bioactive substances in foods (Savaş et al., 2020; Carocho et al., 2018).

\section{Plant-based antioxidant agents}

Vitamins (ascorbic acid and $\alpha$-tocopherol), spices (cinnamon, cloves, nutmeg, ginger, black pepper, and garlic), herbs (rosemary, oregano, marjoram, sage, and basil), and plant extracts (tea, grape seed, cranberry, blueberry, and strawberry) contain antioxidant ingredients (Ahmad et al., 2015; Amiri et al., 2019b). The antioxidant role of plant extracts is because they contain phenolic acids (gallic, protocatechuic, caffeic, and rosmarinic acids), phenolic diterpenes (carnosol, carnosic acid, rosmanol, and rosmadial), flavonoids (quercetin, catechin, naringenin, and kaempferol), and volatile oils (eugenol, carvacrol, thymol, and menthol). Plant pigments such as anthocyanins and anthocyanins also have antioxidant roles. Catechins, epicatechins, phenolic acids, proanthocyanidins, and resveratol confer antioxidant effect in tea and grape seed extract (Aziz and Karboune, 2018; Gonelimali et al., 2018). Ferric acid, a hydroxyaminic acid, is used as an antioxidant and other preservatives in edible films and gels (Kumar and Pruthi, 2014). Catechin is a 3-ol flavon that has antioxidant activity. Ascorbic acid can be used as an oxygen scavengers to stabilize lipids and oils in foods, regenerating phenolic oxidants and oxidized tocopherols. Carotenoids also have antioxidant effects but are sensitive to light oxidation and, therefore, less used. Lycopene is the primary carotenoid in tomatoes. Beta-carotene is used as a singlet oxygen quencher in cooked foods, eggs, and dairy products. As a maker of vitamin $\mathrm{E}$, tocopherols are powerful antioxidants that are used individually or in combination with ascorbic acid (Carocho et al., 2018).

\section{Herb extracts \\ Rosemary}

The antioxidant role of rosemary is found in phenolic diterpens (carnosic, carnosol, rosmanol, rosmadial, 1, 2-methoxycarnosic acid, and epi- and iso-rosmanol) and phenolic acids such as rosmarinic and caffeic acid (Brewer, 2011). Carnosic acid, a hydroxybenzoic acid derivative found in rosemary extract, has the highest antioxidant effect and is used in oils, sauces, bakeries, meat, and fish (Birtić et al., 2015). Rosemary extract E 392 is available on the European Food Additives list (EU Regulation 1129/2011). Rosemary extracts for food preservation alone or with other antioxidants, such as nisin, polyphenols, BHA, and BHT, are examples of the application of natural antioxidants (Carocho et al., 2018). 


\section{Oregano and Sage}

Oregano extract has large amounts of phenolic acids (especially rosmarinic acid), phenolic carboxylic acids, apigenin, dihydroquercetin, and glycoside antioxidant agents that help eliminate superoxide anion radicals (Brewer, 2011). Oregano EO especially reduces lipid and protein oxidation and improves the color of chicken meat (Al-Hijazeen et al., 2016).

\section{Marjoram}

Marjoram EO contains high amounts of rosmarinic acid, carnosol, terpinen-4-ol, cis-sabinene hydrate, p-cumene, and $\Upsilon$-terpinene (Brewer, 2011).

\section{Basil and Thyme}

The main constituents of basil aromas include 3,7-dimethyl-1,6 octadien 3-ol, 1 methoxy 4(2-propenyl) benzene, methyl cinnamate, 4 allyl 2 methoxyphenol, and 1,8 cineole. Eugenol, thymol, carvacrol, and 4 allyl phenol are antioxidant agents comparable to BHT and $\alpha$-tocopherol (Aziz and Karboune, 2018).

\section{Spice extracts}

\section{Cinnamon}

Cinnamon contains the highest amount of polyphenolic compound with the highest antioxidant and antiradical activity. Eugenol and cinnamaldehyde are the most important elements known in cinnamon leaf oil and oleoresin in cinnamon bark. Vanillic, caffeic, gallic, photochatechuic, p-hydroxybenzoic, p-coumaric, ferulic acids, and phydroxybenzaldehyde are also antioxidant components of cinnamon (Brewer, 2011; Bai-Ngew et al., 2021).

\section{Garlic and Onions}

Garlic and myrrh contain the major antioxidants of flavonoids (flavones and quercetins) and the sulfuric components (allyl-cysteine, diallyl sulfide, and allyl trisulfide) (Brewer, 2011). In addition, it has antioxidant roles in vitro and in vivo due to its antimicrobial efficacy. Allicin is one of the major constituents of thiosulfinates in garlic that has a specific garlic odor. When the garlic crumbles, allicin is converted to alliin by alliinase. Onion extracts have higher free radical removal than garlic due to their higher total phenolic content (Aziz and Karboune, 2018). Fresh or oil extract and dried powder of garlic can prevent lipid oxidation and increase sausage persistence (Sallam et al., 2004).

\section{Other spices}

Fresh and dried ginger contains a high concentration of volatile oils of camphene, p-cineole, $\alpha$-terpineol, zingiberene, and pentadecanoic acid. Ginger extract exhibits approximately equal antioxidant activity to BHA and BHT. The main constituents of cumin are cuminal, $\Upsilon$-terpinene, and pinocarveol. The effect of cumin $\mathrm{EO}$ on reducing $\mathrm{Fe}^{3+}$ ions is better than fresh and dried ginger. Turmeric is mainly composed of curcumin, dimethoxycurcumin, bis-dimethoxycurcumin, and 2,5-xylenol, which is associated with vitamin $\mathrm{E}$ and BHT in the removal of free radical. $\alpha$ - and $\beta$-turmerone, curlone, and $\alpha$-terpineol are the most important turmeric oil compounds with antioxidant activity. Black pepper, nutmeg, and cloves also have antioxidant activities (Brewer, 2011; Gonelimali et al., 2018).

\section{Tea and fruit extracts}

Tea and grape seed extracts

Green tea extract has the highest total phenolic content, $94 \%$ of which contains flavonoids. Oolong tea has about $18 \%$ total phenols and $4.4 \%$ flavonoids. In black tea, teaflavins and thearubigins are the predominant ones. The high antioxidant role of tea is due to flavonoids, tannins, and vitamins. Grape seed extract contains catechin and epicatechin. The total phenolic amounts depend on the grape varieties, climatic conditions, degree of maturity, extraction, and solvents (Brewer, 2011).

\section{Pomegranate extracts}

The pomegranate peel contains a good amount of tannins, anthocyanins, and flavonoids. Pomegranate juice has three times more antioxidant effects than green tea and red wine (Ahmad et al., 2015).

\section{Other fruit extracts}

Cranberries have one of the highest levels of total phenol and antioxidant properties among fruits, and citrus fruits have antioxidant efficacy (Ahmad et al., 2015). Citrus fruits contain flavonoids, especially glycosylated flavanones, and polymethoxy flavones. Citrus juice has been reported at about $5-10 \%$ to decrease extra nitrite content and degree of lipid oxidation in tending sausages (Aziz and Karboune, 2018).

\section{Mechanism of action}

Some of the factors that contribute to the oxidation of lipids are oxygen and metal ions, moisture, heat, and light. EOs have different mechanisms, including inhibition of chain initiation and inhibition of hydrogen accumulation, free radical scavengers, termination of peroxides, singlet oxygen formation quenchering, and binding of metal ions (Mahmud and Khan, 2018). Most antioxidants of spices and plants react with free radicals when autoxidation begins, while others form complexes with metal ions. Eighty-five percent EOs are phenolic compounds such as carvacrol, eugenol, and thymol, which are effective 
as primary or fragile chain antioxidants and free radical scavengers (Hyldgaard et al., 2012).

Antioxidants are important components that inhibit autoxidation by preventing the making of free radicals and/or scavenge free radicals by the following mechanisms: Eliminating those that begin to peroxidize, chelating metal ions, quenching ${ }^{\prime} \mathrm{O}_{2}$, which prevent the making of peroxides, fracturing the chain of the oxidation reaction, decreasing oxygen concentration, or stimulating antioxidant enzymes. Antioxidants that are able to disrupt free radical chain reactions are most effective. In general, they have aromatic phenolic rings with hydroxyl groups and can donate $\mathrm{H}^{\otimes}$ to free radicals that convert themselves to radicals. Phenolic acids trap free radicals, and flavonoids can quench free radicals and chelate metals (Brewer, 2011).

\section{Food Applications}

Natural antimicrobial compounds can be used as preservatives in foods. There are two major issues for the application of plant compounds in foods, one being the odor caused by the high concentrations of these substances and the other being the cost. The safety of natural antimicrobials for use in foods is paramount, so toxicity tests must be done before application.

\section{Meat products}

Natural antibacterial components, such as spice and plant extracts, EOs, organic acids, salts, and BACs, are used to modify the shelf life of meat. To improve sausages' retention, lemon and thymol are used with modified atmospheric packaging (MAP). A combination of bay EO and oxygen-free MAP showed that it controls L. monocytogenes and E. coli growing and increases chicken meat's retention time. One study showed that separate extracts of clove, rosemary, cassia bark, and liquorice extracts alone have potent antimicrobial efficacy. The mixture of rosemary and liquorice extracts showed a good repressor effect on L. monocytogenes, E. coli, Pseudomonas fluorescens, and Lactobacillus sake in freshly packed pork slices with atmospheric packaging and vacuum ham slices (Mahmud and Khan, 2018). Nisin, Pediocin PA-1, Enterocin AS-48, Enterocins A and B, sakacin, and leucocin A can be used for bio-preservation of meat products and increase their shelf life. Pediocin is a good bio-preservative in meat products. The antimicrobial efficacy of the mixture of lysozyme, nisin, and EDTA against L. monocytogenes was observed in packed ostrich slices. Immersing meat products in thyme and oregano oil (0.1 and $0.3 \%$ concentrations) improves shelf life (Gonelimali et al., 2018; Rai et al., 2016). Massani et al. (2014) showed that active polymers including Lactobacillus curvatus CRL705 BACs reduced L. monocytogenes levels in
Wiener sausages. Bukvički et al. (2014) studied the efficacy of Satureja horvatii (containing EOs of pcymene, thymol, and thymol methyl ether) on pork meat. In addition to inhibiting L. monocytogenes, these compounds also improved meat color and taste during storage.

\section{Fish products}

$\mathrm{G}^{-}$bacteria spoil fish and fish products. Clostridium spp. and L. monocytogens are responsible for spoilage in vacuum-packed fish. Application of thyme EO and odor leaves increased the shelf life of fish. The combination of MAP and thyme EO increased the retention time of Mediterranean fish fillets. Oregano oil has a strong effect against Photobacterium phosphoreum in codfish fillets than salmon. EOs of Aloysia sellowii were effective on both types of bacteria and two yeasts in brine shrimp. Coating with EOs is a good way to increase the product quality of fish. Also, application of chitosan coated with cinnamon EOs prolongs salmon fillet and increases texture, odor, and color. Nisin can be used to store fish and other seafood. The combination of nisin with MicroGARD is the best way to preserve fish and prevent aerobic microorganisms' growth (Mahmud and Khan, 2018; Rai et al., 2016).

\section{Vegetables and fruits}

Some of the methods used to maintain fruit quality and fresh vegetables are immersion, coating, and spraying. Alginate coating with EOs (lemongrass, cinnamon EOs, citral, and cinnamaldehyde) reduced E. coli O157:H7 in Fuji apple slices and increased their shelf life. Antimicrobial activity of propionic, maleic, acetic, lactic, and citric acid was also demonstrated in red apple and lettuce against E. coli O157:H7, S. typhimurium, and L. monocytogenes. Garlic oil encapsulates in $\beta$-cyclodextrin has influenced the microbial and sensory property of fresh-cut tomatoes. Fruit juices are susceptible to yeasts such as Pichia anomala, S. cerevisiae, and Schizosaccharomyces pombe. Standard processes such as heat treatment, aseptic packaging, or the use of weak acids prevent yeast. EOs are acidic to prevent yeast growth. Lemon EO added to apple juice prolongs the time of "open" storage at room temperature and gives a fresh and pleasant taste (Mahmud and Khan, 2018). Lu et al. (2014) used a washing solution containing thymol that reduced salmonella and total aerobic bacteria in grape tomato without altering its quality.

Enterococci could be applied as starter cultures or cocultures to inhibit microbial contamination. BAC-producing LAB are screened in olives, sourdough, miso, sauerkrauts, refrigerated pickles, and mungbean sprouts. Nisin is used to prevent the growth of C. thermosacchrolyticum and 
Geobacillus stearothermophilus in canned food (canned peas, carrots, and potatoes), fruit juice, and vegetables. Enterocin AS-48 is utilized in fruit juice and canned vegetables to prevent contamination (Rai et al., 2016).

\section{Cereal products}

Chitosan-coated bread improves bread quality by reducing microbial growth and delaying oxidation. The use of citrus oils also affects the sensory characteristics of the bread and inhibits microbial growth. Natural components, for example, anise, black cumin, rosemary, and sage, indicated antimicrobial and antioxidant activity in bakery products. EOs of basil, oregano, and thyme have antibacterial activity against $B$. cereus in rice-based foods (Mahmud and Khan, 2018). The antifungal activity of hydrolyzed goat whey as a bio-preservation agent against Penicillium spp was effective in pita bread (Luz et al., 2020).

\section{Dairy products}

Microorganisms, especially fungi, contaminate dairy products. The effect of natural ingredients has been documented either alone or with other technics such as spraying, immersion, or dusting on milk or cheese directly or in packaging materials. It has been found that mango seed extract reduces bacterial count and inhibits coliforms' growth, has a significant antimicrobial effect on E. coli, and increases the longevity of pasteurized milk. Lysozyme and EDTA in MAP-packaged burrata cheese resulted in increased cheese retention time, particularly at high lysozyme amounts. Enterocin CCM4231 and EJ97 are applied in soy milk and zucchini puree. Entrosine As-48 is used in mangoes, milk, and cheese. Nisin in sodium caseinate films has been used in Babybel mini red cheese (Mahmud and Khan, 2018). Nisin is very effective with other antimicrobial ingredients such as thymol and lysozyme. Lipid nanoparticles with nisin have an antibacterial effect on food pathogens. Pediocin $\mathrm{ACH}$ has shown an antimicrobial effect on L. monocytogens, E. coli, and S. aureus. Oregano and Thyme with MAP have been used in Feta cheese against E. coli O157:H7 and L. monocytogenes. The addition of eucalyptus oil and lemongrass had a high effect on West African soft cheese's nutritional, sensory, and microbial characteristics (Mahmud and Khan, 2018; Rai et al., 2016).

\section{Conclusions}

Given the resistance of microorganisms to antibiotics and consumers' tendency to eat healthy foods, the use of bio-preservatives is a reasonable approach. Some chemical additives may alter specific nutrient properties. For example, sulfites destroy vitamin B1 or nitrate was reduced to nitrite in the meat which converts to carcinogenic nitrosamines. Natural compounds such as EOs of cinnamon, cloves, lemongrass, and their active ingredients are GRAS. The antimicrobial and antioxidant effects of plant extracts and EOs owe to have phenolic compounds such as terpenes and flavonoids. However, despite the tremendous potential, flavor problems and toxicity can limit their use. To alleviate these problems and improve effectiveness, encapsulation of EOs and active compounds and coatings containing these compounds are the best options. Due to the potency of enzymes to produce antimicrobial compounds and their capability to separate some bacteria's outer membrane, they can be known as natural antimicrobials compounds. However, their use in foods needs to be further studied. Bacteriophages are used as an auxiliary process to control some pathogens but do not increase products' shelf life. BACs are antimicrobial or peptide proteins that are ribosomally encoded and widely used in food production. BACs can be used as bio-preservatives because they are safe. The use of antimicrobial peptides in the form of nanoparticles can be very effective. For example, antimicrobial peptide coatings with metal nanoparticles will be beneficial in removing food contamination. The application of films and coatings, including natural agents, is expanding due to their biodegradability and potency to enhance food safety, quality, and shelf life. This study has shown that EOs, BACs, enzymes, organic acids, and coatings can change chemical additives, but more research is needed.

\section{References}

Ahmad, S., Gokulakrishnan, P., Giriprasad, R. and Yatoo, M., 2015. Fruit-based natural antioxidants in meat and meat products: a review. Critical Reviews in Food Science and Nutrition 55(11): 1503-1513. https://doi.org/10.1080/10408398.2012.701674.

Ahmad, V., Khan, M.S., Jamal, Q.M.S., Alzohairy, M.A., Al Karaawi, M.A. and Siddiqui, M.U., 2017. Antimicrobial potential of bacteriocins: in therapy, agriculture and food preservation. International Journal of Antimicrobial Agents 49(1): 1-11. https://doi.org/10.1016/j.ijantimicag.2016.08.016

Aires, A., Mota, V., Saavedra, M., Rosa, E. and Bennett, R., 2009. The antimicrobial effects of glucosinolates and their respective enzymatic hydrolysis products on bacteria isolated from the human intestinal tract. Journal of Applied Microbiology 106(6): 2086-2095. https://doi.org/10.1111/j.1365-2672.2009.04180.x

Al-Hijazeen, M., Lee, E.J., Mendonca, A. and Ahn, D.U., 2016. Effect of oregano essential oil (Origanum vulgare subsp. hirtum) on the storage stability and quality parameters of ground chicken breast meat. Antioxidants 5(2): 18. https://doi.org/10.3390/ antiox 5020018

Amiri, S., Aghamirzaei, M., Mostashari, P., Sarbazi, M., Tizchang, S. and Madahi, H., 2020a. The impact of biotechnology on dairy industry. In Microbial biotechnology in food and health, pp. 53-79. Elsevier. Academic Press. London, United Kingdom. 
Amiri, S., Mokarram, R.R., Khiabani, M.S., Bari, M.R. and Alizadeh, M., 2020b. Optimization of food-grade medium for co-production of bioactive substances by Lactobacillus acidophilus LA-5 for explaining pharmabiotic mechanisms of probiotic. Journal of Food Science and Technology 20: 1-12. https://doi. org/10.1007/s13197-020-04894-5

Amiri, S., Mokarram, R.R., Khiabani, M.S., Bari, M.R. and Khaledabad, M.A., 2019a. Exopolysaccharides production by Lactobacillus acidophilus LA5 and Bifidobacterium animalis subsp. lactis BB12: optimization of fermentation variables and characterization of structure and bioactivities. International Journal of Biological Macromolecules 123: 752-765. https://doi. org/10.1016/j.ijbiomac.2018.11.084

Amiri, S., Mokarram, R.R., Khiabani, M.S., Bari, M.R. and Khaledabad, M.A., 2020c. In situ production of conjugated linoleic acid by Bifidobacterium lactis BB12 and Lactobacillus acidophilus LA5 in milk model medium. LWT 132: 109933. https:// doi.org/10.1016/j.lwt.2020.109933

Amiri, S., Rezazadeh-Bari, M., Alizadeh-Khaledabad, M. and Amiri, S., 2019b. New formulation of vitamin C encapsulation by nanoliposomes: production and evaluation of particle size, stability and control release. Food Science and Biotechnology 28(2): 423-432. https://doi.org/10.1007/s10068-018-0493-z

Amiri, S., Rezazadeh Bari, M., Alizadeh Khaledabad, M., Rezaei Mokarram, R. and Sowti Khiabani, M., 2021b. Fermentation optimization for co-production of postbiotics by Bifidobacterium lactis BB12 in cheese whey. Waste and Biomass Valorization 1-16. https://doi.org/10.1007/s12649-021-01429-7

Amiri, S., Rezazadeh Bari, M., Alizadeh Khaledabad, M., Rezaei Mokarram, R. and Sowti Khiabani, M., 2021c. Co-production of parabiotic metabolites by Lactobacillus acidophilus LA5 and Bifidobacterium animalis subsp. lactis BB12 in dairy effluents. Chemical Review and Letters 4(2), 66-76. https://doi. org/10.22034/crl.2021.253739.1086

Amiri, S., Saray, F.R., Rezazad-Bari, L. and Pirsa, S., 2021a. Optimization of extraction and characterization of physicochemical, structural, thermal, and antioxidant properties of mucilage from Hollyhock's root: a functional heteropolysaccharide. Journal of Food Measurement and Characterization 15, 2889-2903. https://doi.org/10.1007/s11694-021-00870-5

Aziz, M. and Karboune, S., 2018. Natural antimicrobial/antioxidant agents in meat and poultry products as well as fruits and vegetables: a review. Critical Reviews in Food Science and Nutrition 58(3): 486-511. https://doi.org/10.1080/104.08398.2016.1194256

Azizi, S., Bari, M.R., Almasi, H. and Amiri, S., 2021. Microencapsulation of Lactobacillus rhamnosus using sesame protein isolate: effect of encapsulation method and transglutaminase. Food Bioscience 41: 101012. https://doi.org/10.1016/j.fbio.2021.101012

Baines, D. and Seal, R., 2012. Natural food additives, ingredients and flavourings. Elsevier. Woodhead Publishing, Philadelphia, PA, USA.

Bai-Ngew, S., Chuensun, T., Wangtueai, S., Phongthai, S., Jantanasakulwong, K., Rachtanapun, P., ... and Phimolsiripol, Y., 2021. Antimicrobial activity of a crude peptide extract from lablab bean (Dolichos lablab) for semi-dried rice noodles shelflife. Quality Assurance and Safety of Crops \& Foods, 13(2): 25-33. https://doi.org/10.15586/qas.v13i2.882
Banon, S., Díaz, P., Rodríguez, M., Garrido, M.D. and Price, A., 2007. Ascorbate, green tea and grape seed extracts increase the shelf life of low sulphite beef patties. Meat Science 77(4): 626633. https://doi.org/10.1016/j.meatsci.2007.05.015

Bayarri, M., Oulahal, N., Degraeve, P. and Gharsallaoui, A., 2014. Properties of lysozyme/low methoxyl (LM) pectin complexes for antimicrobial edible food packaging. Journal of Food Engineering 131: 18-25. https://doi.org/10.1016/j. jfoodeng.2014.01.013

Birtić, S., Dussort, P., Pierre, F.-X., Bily, A.C. and Roller, M., 2015. Carnosic acid. Phytochemistry 115: 9-19. https://doi. org/10.1016/j.phytochem.2014.12.026

Brewer, M., 2011. Natural antioxidants: sources, compounds, mechanisms of action, and potential applications. Comprehensive Reviews in Food Science and Food Safety 10(4): 221-247. https://doi.org/10.1111/j.1541-4337.2011.00156.x

Bukvički, D., Stojković, D., Soković, M., Vannini, L., Montanari, C., Pejin, B., et al. 2014. Satureja horvatii essential oil: in vitro antimicrobial and antiradical properties and in situ control of Listeria monocytogenes in pork meat. Meat Science 96(3): 13551360. https://doi.org/10.1016/j.meatsci.2013.11.024

Burrowes, O., Hadjicharalambous, C., Diamond, G. and LEE, T.C., 2004. Evaluation of antimicrobial spectrum and cytotoxic activity of pleurocidin for food applications. Journal of Food Science 69(3), FMS66-FMS71. https://doi. org/10.1111/j.1365-2621.2004.tb13373.x

Campos, C.A., Gerschenson, L.N. and Flores, S.K., 2011. Development of edible films and coatings with antimicrobial activity. Food and Bioprocess Technology 4(6): 849-875. https:// doi.org/10.1007/s11947-010-0434-1

Carocho, M., Morales, P. and Ferreira, I.C., 2018. Antioxidants: reviewing the chemistry, food applications, legislation and role as preservatives. Trends in Food Science \& Technology 71: 107120. https://doi.org/10.1016/j.tifs.2017.11.008

Carvalho, C., Costa, A.R., Silva, F. and Oliveira, A., 2017. Bacteriophages and their derivatives for the treatment and control of food-producing animal infections. Critical Reviews in Microbiology 43(5): 583-601. https://doi.org/10.1080/10408 41X.2016.1271309

Chibeu, A., Agius, L., Gao, A., Sabour, P.M., Kropinski, A.M. and Balamurugan, S., 2013. Efficacy of bacteriophage LISTEX ${ }^{\text {ma }}$ P100 combined with chemical antimicrobials in reducing Listeria monocytogenes in cooked turkey and roast beef. International Journal of Food Microbiology 167(2): 208-214. https://doi. org/10.1016/j.ijfoodmicro.2013.08.018

Cui, H., Yuan, L. and Lin, L., 2017. Novel chitosan film embedded with liposome-encapsulated phage for biocontrol of Escherichia coli O157: H7 in beef. Carbohydrate Polymers 177: 156-164. https://doi.org/10.1016/j.carbpol.2017.08.137

Díez, L., Rojo-Bezares, B., Zarazaga, M., Rodríguez, J.M., Torres, C. and Ruiz-Larrea, F., 2012. Antimicrobial activity of pediocin PA-1 against Oenococcus oeni and other wine bacteria. Food Microbiology 31(2): 167-172. https://doi.org/10.1016/j. fm.2012.03.006

Dussault, D., Vu, K.D. and Lacroix, M., 2014. In vitro evaluation of antimicrobial activities of various commercial essential oils, 
oleoresin and pure compounds against food pathogens and application in ham. Meat Science 96(1): 514-520. https://doi. org/10.1016/j.meatsci.2013.08.015

Dutta, P., Tripathi, S., Mehrotra, G. and Dutta, J., 2009. Perspectives for chitosan based antimicrobial films in food applications. Food Chemistry 114(4): 1173-1182. https://doi.org/10.1016/j. foodchem.2008.11.047

Elbarbary, H.A., Abdou, A.M., Nakamura, Y., Park, E.Y., Mohamed, H.A. and Sato, K., 2012. Identification of novel antibacterial peptides isolated from a commercially available casein hydrolysate by autofocusing technique. Biofactors 38(4): 309-315. https:// doi.org/10.1002/biof.1023

Embuscado, M.E., 2015. Spices and herbs: natural sources of antioxidants-a mini review. Journal of functional foods 18: 811819. https://doi.org/10.1016/j.jff.2015.03.005

Favaro, L., Penna, A.L.B. and Todorov, S.D., 2015. Bacteriocinogenic LAB from cheeses-application in biopreservation? Trends in Food Science \& Technology 41(1): 37-48. https://doi. org/10.1016/j.tifs.2014.09.001

Ghamari, M.A., Amiri, S., Rezazadeh-Bari, M. and Rezazad-Bari, L., 2021. Physical, mechanical, and antimicrobial properties of active edible film based on milk proteins incorporated with Nigella sativa essential oil. Polymer Bulletin 1-21. https://doi. org/10.1007/s00289-021-03550-y

Gholam-Zhiyan, A., Amiri, S., Rezazadeh-Bari, M. and Pirsa, S., 2021. Stability of Bacillus coagulans IBRC-M 10807 and Lactobacillus plantarum PTCC 1058 in Milk Proteins Concentrate (MPC)Based Edible Film. Journal of Packaging Technology and Research 5: 11-22. https://doi.org/10.1007/s41783-021-00106-3

Gonelimali, F.D., Lin, J., Miao, W., Xuan, J., Charles, F., Chen, M., et al. 2018. Antimicrobial properties and mechanism of action of some plant extracts against food pathogens and spoilage microorganisms. Frontiers in Microbiology 9:1639. https://doi. org/10.3389/fmicb.2018.01639

Gyawali, R. and Ibrahim, S.A., 2014. Natural products as antimicrobial agents. Food Control 46: 412-429. https://doi.org/10.1016/j. foodcont.2014.05.047

Hyldgaard, M., Mygind, T. and Meyer, R.L., 2012. Essential oils in food preservation: mode of action, synergies, and interactions with food matrix components. Frontiers in Microbiology 3: 12. https://doi.org/10.3389/fmicb.2012.00012

Ibrahim, S.A., Salameh, M., Phetsomphou, S., Yang, H. and Seo, C., 2006. Application of caffeine, 1, 3, 7-trimethylxanthine, to control Escherichia coli O157: H7. Food Chemistry 99(4): 645-650. https://doi.org/10.1016/j.foodchem.2005.08.026

Irkin, R. and Esmer, O.K., 2015. Novel food packaging systems with natural antimicrobial agents. Journal of Food Science and Technology 52(10): 6095-6111. https://doi.org/10.1007/s13197-015-1780-9

Jenssen, H. and Hancock, R.E., 2009. Antimicrobial properties of lactoferrin. Biochimie 91(1): 19-29. https://doi.org/10.1016/j. biochi.2008.05.015

Juneja, V.K., Dwivedi, H.P. and Yan, X., 2012. Novel natural food antimicrobials. Annual Review of Food Science and Technology 3: 381-403. https://doi.org/10.1146/annurev-food-022811-101241

Khaneghah, A. M., Hashemi, S. M. B. and Limbo, S. 2018. Antimicrobial agents and packaging systems in antimicrobial active food packaging: An overview of approaches and interactions. Food and Bioproducts Processing, 111: 1-19. https://doi. org/10.1016/j.fbp.2018.05.001

Kim, S. and Fung, D., 2004. Antibacterial effect of crude water-soluble arrowroot (Puerariae radix) tea extracts on foodborne pathogens in liquid medium. Letters in Applied Microbiology 39(4): 319-325. https://doi.org/10.1111/j.1472-765X.2004.01582.x

Kumar, N. and Pruthi, V., 2014. Potential applications of ferulic acid from natural sources. Biotechnology Reports 4: 86-93. https:// doi.org/10.1016/j.btre.2014.09.002

Lone, A., Anany, H., Hakeem, M., Aguis, L., Avdjian, A.-C., Bouget, M., et al. 2016. Development of prototypes of bioactive packaging materials based on immobilized bacteriophages for control of growth of bacterial pathogens in foods. International Journal of Food Microbiology 217: 49-58. https:// doi.org/10.1016/j.ijfoodmicro.2015.10.011

Lu, Y., Joerger, R. and Wu, C., 2014. Similar reduction of Salmonella enterica Typhimurium on grape tomatoes and its crosscontamination in wash water by washing with natural antimicrobials as compared with chlorine treatment. Food and Bioprocess Technology 7(3): 661-670. https://doi.org/10.1007/ s11947-013-1105-9

Luz, C., Izzo, L., Ritieni, A., Mañes, J. and Meca, G., 2020. Antifungal and antimycotoxigenic activity of hydrolyzed goat whey on Penicillium spp: an application as biopreservation agent in pita bread. LWT 118: 108717. https://doi.org/10.1016/j. lwt.2019.108717

Mahmud, J. and Khan, R.A., 2018. Characterization of natural antimicrobials in food system. Advances in Microbiology 8(11): 894. https://doi.org/10.4236/aim.2018.811060

Maleki, O., Khaledabad, M.A., Amiri, S., Asl, A.K. and Makouie, S., 2020. Microencapsulation of Lactobacillus rhamnosus ATCC 7469 in whey protein isolate-crystalline nanocellulose-inulin composite enhanced gastrointestinal survivability. LWT 126: 109224. https://doi.org/10.1016/j.lwt.2020.109224

Marei, G.I.K., Rasoul, M.A.A. and Abdelgaleil, S.A., 2012. Comparative antifungal activities and biochemical effects of monoterpenes on plant pathogenic fungi. Pesticide Biochemistry and Physiology 103(1): 56-61. https://doi.org/10.1016/j.pestbp.2012.03.004

Martínez-García, M., Bart, J.-M., Campos-Salinas, J., Valdivia, E., Martínez-Bueno, M., González-Rey, E., et al. 2018. Autophagicrelated cell death of Trypanosoma brucei induced by bacteriocin AS-48. International Journal for Parasitology: Drugs and Drug Resistance 8(2), 203-212. https://doi.org/10.1016/j. ijpddr.2018.03.002

Massani, M.B., Molina, V., Sanchez, M., Renaud, V., Eisenberg, P. and Vignolo, G., 2014. Active polymers containing Lactobacillus curvatus CRL705 bacteriocins: effectiveness assessment in Wieners. International Journal of Food Microbiology 178: 7-12. https://doi.org/10.1016/j.ijfoodmicro.2014.02.013

Milicevic, B., Tomović, V., Danilović, B. and Savić, D., 2021. The influence of starter cultures on the lactic acid bacteria microbiota of Petrovac sausage. Italian Journal of Food Science, 33(2), 24-34. https://doi.org/10.15586/ijfs.v33i2.1918

Mohajeri, N., Shotorbani, P. M., Basti, A. A., Khoshkhoo, Z. and Khanjari, A., 2021. An assessment of Cuminum cyminum (Boiss) 
essential oil, $\mathrm{NaCl}$, bile salts and their combinations in probiotic yogurt. Italian Journal of Food Science, 33(SP1), 24-33. https:// doi.org/10.15586/ijfs.v33iSP1.1990

Moghanjougi, Z.M., Bari, M.R., Khaledabad, M.A., Almasi, H. and Amiri, S., 2020. Bio-preservation of white brined cheese (Feta) by using probiotic bacteria immobilized in bacterial cellulose: optimization by response surface method and characterization. LWT 117: 108603. https://doi.org/10.1016/j.lwt.2019.108603

Montiel, R., Martín-Cabrejas, I., Langa, S., El Aouad, N., Arqués, J., Reyes, F., et al. 2014. Antimicrobial activity of reuterin produced by Lactobacillus reuteri on Listeria monocytogenes in cold-smoked salmon. Food Microbiology 44: 1-5. https://doi. org/10.1016/j.fm.2014.05.006

Oranusi, S., Braide, W. and Oguoma, O., 2013. Antifungal properties of lactic acid bacteria (LAB) isolated from Ricinus communis, Pentaclethra macrophylla and Yoghurts. Global Advanced Research Journal of Food Science and Technology 2(1): 001-006. http://garj.org/garjfst/2/2013/2/1/antifungal-properties-of-lacticacid-bacteria-isolated-from-ricinus-communis-pentaclethra-macrophylla-and-yoghurts

Pisoschi, A.M., Pop, A., Georgescu, C., Turcuş, V., Olah, N.K. and Mathe, E., 2018. An overview of natural antimicrobials role in food. European Journal of Medicinal Chemistry 143: 922-935. https://doi.org/10.1016/j.ejmech.2017.11.095

Prakash, B., Singh, P., Mishra, P.K. and Dubey, N., 2012. Safety assessment of Zanthoxylum alatum Roxb. essential oil, its antifungal, antiaflatoxin, antioxidant activity and efficacy as antimicrobial in preservation of Piper nigrum L. fruits. International Journal of Food Microbiology 153(1-2): 183-191. https://doi. org/10.1016/j.ijfoodmicro.2011.11.007

Rai, M., Pandit, R., Gaikwad, S. and Kövics, G., 2016. Antimicrobial peptides as natural bio-preservative to enhance the shelf-life of food. Journal of Food Science and Technology 53(9): 3381-3394. https://doi.org/10.1007/s13197-016-2318-5

Regnault-Roger, C., Vincent, C. and Arnason, J.T., 2012. Essential oils in insect control: low-risk products in a high-stakes world. Annual Review of Entomology 57: 405-424. https://doi. org/10.1146/annurev-ento-120710-100554

Rezazadeh-Bari, M., Najafi-Darmian, Y., Alizadeh, M. and Amiri, S., 2019. Numerical optimization of probiotic Ayran production based on whey containing transglutaminase and Aloe vera gel. Journal of Food Science and Technology 56(7): 3502-3512. https://doi.org/10.1007/s13197-019-03841-3

Sagdic, O., Aksoy, A. and Ozkan, G. 2006. Evaluation of the antibacterial and antioxidant potentials of cranberry (gilaburu, Viburnum opulus L.) fruit extract. Acta Alimentaria 35(4): 487492. https://doi.org/10.1556/AAlim.35.2006.4.12

Sallam, K.I., Ishioroshi, M. and Samejima, K., 2004. Antioxidant and antimicrobial effects of garlic in chicken sausage. LWTFood Science and Technology 37(8): 849-855. https://doi. org/10.1016/j.lwt.2004.04.001

Savaş, E., Tavşanlı, H., Çatalkaya, G., Çapanoğlu, E. and Tamer, C. E., 2020. The antimicrobial and antioxidant properties of garagurt: traditional Cornelian cherry (Cornus mas) marmalade. Quality Assurance and Safety of Crops \& Foods, 12(2), 12-23. https:// doi.org/10.15586/qas.v12i2.627

Shan, B., Cai, Y.-Z., Brooks, J.D. and Corke, H., 2007. Antibacterial properties and major bioactive components of cinnamon stick (Cinnamomum burmannii): activity against foodborne pathogenic bacteria. Journal of Agricultural and Food Chemistry 55(14): 5484-5490. https://doi.org/10.1021/jf070424d

Silva, F. and Domingues, F.C., 2017. Antimicrobial activity of coriander oil and its effectiveness as food preservative. Critical Reviews in Food Science and Nutrition 57(1): 35-47. https://doi. org/10.1080/10408398.2013.847818

Sohrabpour, S., Rezazadeh Bari, M., Alizadeh, M. and Amiri, S., 2021. Investigation of the rheological, microbial, and physicochemical properties of developed synbiotic yogurt containing Lactobacillus acidophilus LA-5, honey, and cinnamon extract. Journal of Food Processing and Preservation 45(4): e15323. https://doi.org/10.1111/jfpp.15323

Tajkarimi, M., Ibrahim, S.A. and Cliver, D., 2010. Antimicrobial herb and spice compounds in food. Food Control 21(9): 11991218. https://doi.org/10.1111/jfpp.15323

Tiwari, B.K., Valdramidis, V.P., O’Donnell, C.P., Muthukumarappan, K., Bourke, P. and Cullen, P., 2009. Application of natural antimicrobials for food preservation. Journal of Agricultural and Food Chemistry 57(14): 5987-6000. https://doi.org/10.1021/jf900668n

Tongnuanchan, P. and Benjakul, S., 2014. Essential oils: extraction, bioactivities, and their uses for food preservation. Journal of Food Science 79(7): R1231-R1249. https://doi. org/10.1111/1750-3841.124.92

Tumbarski, Y., Petkova, N., Todorova, M., Ivanov, I., Deseva, I., Mihaylova, D. and Ibrahim, S. A., 2020. Effects of pectin-based edible coatings containing a bacteriocin of bacillus methylotrophicus bm47 on the quality and storage life of fresh blackberries. Italian Journal of Food Science, 32(2). https://doi. org/10.14674/IJFS-1663

Upendra, R., Khandelwal, P., Jana, K., Ajay Kumar, N., Gayathri Devi, M. and Stephaney, M.L., 2016. Bacteriocin production from indigenous strains of lactic acid bacteria isolated from selected fermented food sources. International Journal of Pharma Research and Health Sciences 4(1): 982-990.

Varsha, K.K. and Nampoothiri, K.M., 2016. Appraisal of lactic acid bacteria as protective cultures. Food Control 69: 61-64. https:// doi.org/10.1016/j.foodcont.2016.04.032

Wang, S., Zeng, X., Yang, Q. and Qiao, S., 2016. Antimicrobial peptides as potential alternatives to antibiotics in food animal industry. International Journal of Molecular Sciences 17(5): 603. https://doi.org/10.3390/ijms17050603

Xing, Y., Xu, Q., Li, X., Che, Z. and Yun, J., 2012. Antifungal activities of clove oil against Rhizopus nigricans, Aspergillus flavus and Penicillium citrinum in vitro and in wounded fruit test. Journal of Food Safety 32(1): 84-93. https://doi. org/10.1111/j.1745-4565.2011.00347.x 